\title{
Visionary Leadership Insides Government of Banten Province, Indonesia: A Study of 2007-2012 Era
}

\author{
Andriansyah \\ University of Prof. Dr. Moestopo (Beragama) \\ Jalan Hang Lekir, Jakarta, Indonesia \\ andriansyah@dsn.moestopo.ac.id
}

\begin{abstract}
This study aims on discussing visionary leadership of the Local Head of Banten Province and producing a new concept for the development of science, Governance Studies in particular. The object of this study is visionary leadership of the Local Head of Banten Province. Banten province is a concrete example to be the standard for viewing the quality of leadership vision of local head selected in a local general election. This article analyzes how far a local head applies visionary leadership in the management of local governance. Reaching this goal, a qualitative approach is employed. The era of Ratu Atut Chosiyah (as the leader of Banten Province) office term is appealing to study considering her being the first female governor not only in Banten, but also in Indonesia. By further observing the strength of visionary leadership during Governor Ratu Atut Chosiyah (2007-2012) era, an analysis is conducted employing four vital roles of a leader in developing visionary leadership as the approach. These four roles include the leader as spokesperson, the leader as director, the leader as coach, and the leader as agent of change. It is concluded that the challenge of changing bureaucratic culture is the main problem to solve.
\end{abstract}

Keywords: Analysis; Visionary; Leadership; Banten Province.

\section{Introduction}

For more than a decade, Indonesia has experienced a very dynamic and open local democratic process through decentralization and local head general election. Decentralization is the actualization of local welfare demand, as is declared by Greer in [1] that decentralization has the potency of improving the standard of prosperity. The success of decentralization in reaching welfare goal depends heavily on the capacity of local head. On the other hand, Pratchett in [2] identifies decentralization as a strong justification for establishing local democracy. Local democracy is the manifestation of implementation of political decentralization at local level. Panday in [3] believes that it is important for a democracy to have a self-governing local government system which is accountable to the highest authority. General Election of local head is the sign of actual implementation of democracy at regional level. It delivers new leaders at local level with various leadership styles. Nankyung in [4] mentions that the impact of general election of local head depends on how well the local politic leader actor interprets and responds to the interest of their groups. Therefore, without a strong leadership, there is a high probability of conflict in the regions. Moving towards a good local democracy as desired, Haugaard in [5] states that it took 500 years for Europe to advance. Initially under a lot of pressure, democracy gradually alters its direction into a real political force. Compared this to local democracy in Indonesia which only transpires for no more than 2 decades, it is clear that local leaders in Indonesia must face greater demands in developing prosperity in their territories. 
The presence of local leaders elected democratically in Indonesia is stipulated by the amendment of article 18 point (4) of Indonesian 1945 Constitution which states: Governor, Regent, and Mayor consecutively the leader of province, regency and city are elected democratically. After publication of Law Number 32 Year 2004 on Local Government, all Governor, Regent and Mayor Positions are selected in a democratic general election. However, the quality of the local leaders elected in this fashion often stirs doubt among public, in particular concerning their capacity in guiding the region into a better prosperity level. This local head quality phenomenon is the highlight of this article which questions: How good is the quality of leadership of local heads elected in general election in particular concerning the demand for prosperity as the aspiration of decentralization in Indonesia?

Banten Province is a concrete example to be the standard for viewing the quality of leadership of local head elected in a general election. Some interesting facts can be highlighted in this matter, among others the election of a Female Governor, an inclination commonly transpires in developing countries. Rahman in [6] believes that in developing countries, the presence of women in political space in general is unseparated from role of kinship such as family network. This means that public trust derives more from the factor of strong family.

Another interesting fact is that the General Election of Banten Governor in 2011 shows a low rate of public participant in the election of less than 50\%, which demonstrates pessimism of public towards their local leader. This raises question on how far a local head with a vision can appeal to public hope including on the matter of prosperity. Hesselbein in [7], Kouzes and Posner in [8], and Nanus in [9,10] believe that vision is important as a standard of a leader. Based on this fact, this paper aims at analyzing how far a local leader applying visionary leadership in the management of local government. To accomplish this goal, qualitative approach is employed in which primary data is collected through FGD process and snowball technique interview involving stakeholders and public officials in Banten Provincial Government circle. Secondary data is collected through intensive desk study using various literary and documentary sources.

The rest of this paper is organized as follow: Section 2 presents the notion of visionary leadership concept. Section 3 presents the main results on visionary leadership in Banten provincial government, Indonesia. Section 4 presents the conclusion of this work.

\section{Visionary Leadership Concept}

Leadership concept plays a vital role in the implementation of organization and management as the defining factor for the direction of organization wheel movement. In this matter, Miller, et al. in [11] finds that leadership can be defined as a social interactive process in which the one plays the role of a leader can influence others playing the role of followers or the led party to do something in order to achieve a certain goal. This capacity to influence others is also revealed by Rasyid in [12] who believes that leadership is the summary of the concept of interactive influence between leader and follower in chasing mutual goal. This opinion of Miller, et al. in [11] and Rasyid in [12] underlines that leadership is the actualization of leader's influence in correlation with mutual goal of the organization. Achieving the goal of the organization, leadership must be effective. Jackson, et al. in [13] states that very effective leaders will build their leadership on a foundation comprising of three core values, namely integrity, vassal heart, and willingness for stewardship. These three matters are vital for the development of any organization and allow the creation of a good and productive team. This personal perspective of Jackson, et al. in [13] is dissimilar to Yukl in [14] who observes from a more managerial perspective that effective leadership is more inclined to include: duty oriented behavior; relation oriented behavior; and participative leadership. 
However, the three leadership behaviors explained by both Jackson, et al. in [13] and Yukl in [14] have not shown the role of leaders in their social environment as determining factor. Hesselbein in [7] conveys a different thought where he perceives true leadership can only be defined meaningfully in a social context; namely that the vision possessing social meaning and other leadership values must be established on a standard benefitting the public. The standard mentioned can be attached to the actions of the leader. This opinion of Hesselbein in [7] is shared by Kouzes and Posner in [8] proposing leader's commitment to mutual vision. Kouzes and Posner in [8] explain that the leader must be aware of his words and how he acts consistently to the words he said. Along with this consistency, a leader must also actualize himself as the best person worthy of being example for public and able to inspire mutual vision.

This establishment of mutual vision is essential as is proposed by Kouzes and Posner in [8] explaining that every organization, every social movement is started with a dream. Dream or vision is the power to create future. Therefore, a leader must be able to inspire mutual vision. However, Hesselbein in [7] states that not every leadership vision shares the same value. Some are more important and socially significant than others. True leadership must lead to a change bringing social improvement. It is apparent that true leadership must not support the vision of the process which generates social injustice.

Then, what kind of vision is correct? Nanus in $[9,10]$ states that vision always concerns future; vision shows us what to do in actualizing it. Vision possesses strong force to create future. By this vision, organization's mission and goals are designed. By this vision, a leader actualizes visionary leadership between him and those he leads. In this context, Nanus in $[9,10]$ says that vision plays a vital role not only at the start-up stage but also through the entire life cycle of the organization. Vision is the sign showing the way for everybody to understand organization and where it is directed. Therefore, Nanus in $[9,10]$ explains that an effective leader not only has to be smart in building relations, but also in giving guidance, push and motivation. A leader is required to be able to take advantage from external environment of the organization and ensures that organization is in good position in anticipating condition of the environment affecting organization. A leader is required to be able to influence all operational aspects of the organization in developing product and service, production process, quality control system, organization structure, and information system. In the end, a leader is also required to be able to anticipate future challenge affecting the organization.

Further, Nanus in $[9,10]$ proposes four vital roles of leader in developing effective visionary leadership. With the illustration of leader's roles he depicted, Nanus in $[9,10]$ shows that there are four vital roles of leader in developing visionary leadership. Those four roles are leader as spokesperson, as direction setter, as coach, and as agent of change. Visionary leadership is the capacity of leader in creating, formulating, communicating/socializing, transforming, and implementing ideal thoughts generated both from himself and as the result of social interaction between members and stakeholders of the organization believed to be future goals of the organization which must be accomplished or actualized through commitment of all personnel. To be a visionary leader, one must comprehends concept, characteristics and elements, and goal of the vision. Vision must be refreshed to always be concurrent and adequate to changes of environment. Therefore, vision in this context is a main attribute of a leader. It is the duty and responsibility of leader to deliver, nurture, develop, apply and refresh vision to be able to provide accurate and fast respond to various challenges and demands faced by the organization. It is apparent that vision can be processed, engineered, and grown.

\subsection{The Urgency for Visionary Leadership in Indonesia}

In his book, Koentjaraningrat in [15] discloses that the factor of mental attitude of the majority of Indonesian people is still inappropriate for development, both from cultural 
value system and attitude aspects. This flaw is related to the lack of work-quality based on the concept that we work for the output of producing more work (less productive), unwillingness to save money based on future orientation and lack of pure discipline and responsibility so that preparing for development will take public awareness to produce quality work, willingness to save money based on future orientation, and possession of pure discipline and responsibility. Correct stimulations are required in emerging this positive mental attitude. On the other hand, Indonesian public, just as other developing countries, is a dualistic public (borrowing the term of Boeke in [16]). On one hand they play the part of agrarian, traditional, and feudal-inclined public, while on the other hand they also play the part of industrial public just like the countries with fast economic growth. Western modernity, modern ideas, demand for freedom of thinking and acting become stronger along with the fast and unstoppable flow of information which is commonly happened. This dualism is geographically polarized, agrarian cultured people lives in rural area while industrial cultured people lives in urban area; although the fast flow of information starts to allow modernity into rural area. Despite modernity driven life, the people of Indonesia is fundamentally still attached to agrarian culture. Feudal culture inclining to patronize person they regard possessing great influence is inevitable.

With the skeptical and indifferent tendency of public behavior at present, public leader inclined to emphasize more on the image emerging which suits their position at present. In such feudal society, dialogical communication capacity between the figure and public cannot transpire since public is disinclined to have a dialogue with the patron. Meanwhile, bottom up participative communication also cannot transpire since the public themselves feel incapable to channel their aspiration through the figure. Drawing an analogy of leadership phenomenon in Indonesia today, something interesting for analysis emerges. Political communication in Indonesia today is modern political communication applying ways commonly used in developed countries. Maximum utilization of information flow has been implemented massively in Indonesia although cannot be categorized as sophisticated yet. Political messages conveyed are not deeply delved so that the independent and effective communication media in the end is only used in polishing the image of political leader without the least mentioning of the root of public matter substances.

This makes the manifestation of modern campaign in general election transpired in Indonesia shallow and insubstantial. Campaign is taken for the purpose of mere imaging and deification of leader, which only concerns with the effort of increasing political charisma and this is very effective in feudal cultured society, in rural area in particular. Meanwhile, modern campaign proposing intellectuality, accountability, and capability of character cannot proceed since public themselves, although utilizing information technology in modern way, still feel incapable of entering more intellectual domain. This phenomenon is called future shock phenomenon by Toffler in [17] where individual or public trapped inside a slow changing environment must suddenly adapt to a new environment demanding fast and complex changes; in the end public experiences stress or disorientation by the many changes in such a short time. This is what Indonesia faces. Culture changes rapidly while public themselves are not ready to change. This can be perceived in the manifestation of political campaign which is modern but still cannot show leader's intellectuality which should be the highlight of society claimed to be moving towards modernity.

In time, without national awareness, local leaders with such feudal characteristics will try to maintain their reign in such a way that can end in disintegration of the nation. Sugiarto in [18] believes that this nation actually needs a combination of strong leadership style and visionary capacity and ability to build new culture and perspective. Resoluteness without guidance by vision and guard by conscience will only give birth to a new dictator. Visionary capacity without resoluteness and logic will only create a nation full of talk and less work. Sugiarto believes that with the dynamics transpires today, no wonder many 
believes that structural changes fail to be followed by cultural changes when transactional trait of leaders still fill political stage. It will take a fundamental change of cultural aspect for the eradication of corruption and maintaining of clean governance. This nation needs direction of a visionary or transformational leadership, a leadership characteristic focusing on the change at value level. In actualization of prime services for public, a leader must dare to change. The changes an Indonesian leader can bring to improve quality of public service, according to Sanapiah [20] are among others:

a. Cutting off irrelevant bureaucracy.

b. Applying contestability (comparing service conducted by one's own organization unit with other organization to see its effectiveness and efficiency) or even developing contract with private sector (if this is the most effective and efficient way to do).

c. Employing various new technologies to improve quality of public service.

d. Developing customer focus public service.

The demand for improving public service condition at present gets bigger and becomes the main agenda in national life. A visionary leader must be able to conduct changes towards systematic and measured improvement. However, various more internal reform efforts must also be followed by the development of external strategy. This strategy is directed on the development of 'good image' of organization and service provided by public organization. Only a correct strategy of a leader can unite all components of the nation from the negative effect of decentralization.

\section{Visionary Leadership in Banten Provincial Government, Indonesia}

Visionary leadership in Banten province can be traced back to the past era of the Sultanate. In the early $17^{\text {th }}$ Century, Banten Sultanate was one of the biggest ports in Asia in international trade line, along with Makassar and Malaka. Visionary leadership trace reached its peak in the era of Sultan Ageng Tirtayasa who was successful in controlling trade in Southeast Asia, expanding Sultanate territory to include the south part of Sumatera and opening diplomatic and trading relation with the United Kingdom. This leadership golden era of Banten was gradually fading and ended in the $19^{\text {th }}$ Century. Leadership in Banten province has a post-reform resurgence through area expansion or new autonomy area creation following legalization of Law Number 22 Year 1999 on the Autonomy Area later revised into Law Number 32 Year 2004. Banten Province is an autonomy area established by Law Number 23 Year 2000 [20]. Prior to becoming a province, Banten is a part of West Java province. The plenary session of the House of Representatives in 4 October 2000 legitimated Banten Province Draft into Law is set as the birthday of Banten Province [21]. On 18 November 2000, Banten Province is officiated and H. Hakamudin Djamal is inaugurated as acting governor to run the governance of Banten Province until a definitive governor was elected [21]. The period of Banten Provincial governor since its establishment up to now are as follows: 1) Hakamudin Djamal as the First Acting Governor (2000-2002); 2) Djoko Munandar-Ratu Atut Chosiyah (2002-2005); 3) Ratu Atut Chosiyah as Acting Governor of Banten (20052007); 4) Ratu Atut Chosiyah-Masduki (2007-2012) , 5) Ratu Atut Chosiyah-Rano Karno (2012-2013), 6) Rano Karno (2013-2017).

The gubernatorial era of Ratu Atut Chosiyah is appealing for analysis considering her position as the first Female Governor, not only in Banten but also in Indonesia. Women position in governmental leadership in developing countries is inclined to develop in a unique way. Rahman in [6] believes that in developing countries the presence of women in political space in general is unseparated from the role of kinship such as family network. This means public trust derives more form strong family factor. This kinship factor will surely affect the vision of a leader on the territory. Viewing further the strength of visionary leadership in gubernatorial era of Ratu Atut Chosiyah (2007-2012), analysis can be drawn by employing Nanus' opinion of the four vital roles of leader in developing 
visionary leadership, namely as spoke person, as direction setter, as coach, and as agent of change $[9,10]$. By this theoretical approach, then the phenomenon of visionary leadership of Local Head of Banten Province is revealed through the four strategic roles of Local Head, namely Local Head role as a spokesperson, Local Head role as a direction setter, Local Head role as a coach, and Local Head role as an agent of change.

\subsection{Local Head Role as a Spokesperson}

In the perspective of implementing local government system, there is a government leadership mechanism focuses on the role of Local Head as top executive. To actualize this leadership of the Local Head, when a candidate and his partner participate in Local Head Election, he must propose his leadership vision and mission. This vision and mission proposal is one of the requirements that must be fulfilled by every candidatepairing wishing to participate in the election. Therefore, ever since his first appearance, the Local Head candidate is required to be a visionary leader. Thus, before and after becoming a Local Head, one must possess comprehensive and extensive consideration on the matters on which his vision and mission as a Local Head are grounded. For instance, what consideration is the foundation of Banten Province Development Vision, "Prosperous People of Banten on the Basis of Faith and Piety".

Comprehensive understanding of internal and external condition of the government must become the vital considerations for Local Head of Banten Province in actualizing his leadership concept. In government internal dimension, a complete understanding is needed to select and determine the correct managerial approach pattern to optimalize and synergize every step of bureaucratic leadership. Meanwhile, in government external dimension, a complete understanding is needed to select and determine the correct sociological approach to motivate and move various public elements. One of the sociological approach needed in motivating and moving Banten people who are known as religious is by giving appreciation and the widest space for the development of belief and custom as the characteristics of Banten people.

Referring to contemplating perspective in perceiving the problems and aspects of Religious people of Banten who still hold fast to belief and custom, it seems that the Local Head is also required to possess bureaucratic perception and understand how the development management system works. This bureaucratic perception refers to the hierarchical structure of local government, while the development management has been systemically patterned in a Local Middle Term Development Plan (LMTDP). This development planning pattern progressing for five years then is elaborated by Local Apparatus Work Unit (SKPD) into SKPD strategic plans and elaborated further into SKPD Annual Work Plan. In this context, the Local Head appears as top manager who plays the role of giving direction and conducting control on the implementation of various programs and development activities. Interview with sources reveals that it is not easy to actualize the ten good governance principles since it does not only require the readiness and preparation of apparatus resources but also requires a government leadership capacity that is competent and capable of making changes in bureaucratic culture.

The presence of phenomenon of government performance that cannot show changes for the better is a proof of the weakness of national government in changing bureaucratic culture, laden with corruption. In addition, work culture of the apparatus that is unproductive, ignoring quality, and inefficient, is organizational problems that need to be responded, overcome, and simultaneously anticipated with critical, careful, and accurate approach pattern to change the process of work culture into more productive. Therefore, the factor of Local Head leadership in implementation of decentralization policy and local autonomy becomes more vital and strategic for the actualization of democratic implementation that can actualize public welfare. The reality that the development implementation in Banten Province has not wholly overcome the problems among Banten 
people is a reality that is not just the actual challenge for the Governor of Banten, but also for all the Regents and Mayors in Banten Province. However, the leadership of the Local Head of Banten Province is still the dominant factor of local government leadership since the Governor is the representative of the government. It means that the leadership concept of the Local Head of Banten Province is still vital and strategic for the implementation of development management system in the area.

The leadership pattern of the Local Head of Banten Province is closely attached to local development management pattern composed every five years. Since the sequence of contents in the development management pattern originated from the vision and mission of the Local Head prior to his appointment in Local Head Election, automatically this development management pattern attached to the vision and mission of the local head leadership. To achieve this vision and mission, a Local Head surely develops various leadership approaches which are appropriate to each leadership situation he faces. The interview reveals a concept of "creative leadership" which seems to be an attractive title for enriching government leadership style. Therefore, creative government leadership style that still notices various binding stipulations must be developed to make a government leadership style which is dynamic, daring, and capable of infiltrating various political and administrative obstacles which do not need to exist. It is indeed not easy to develop creative government leadership style since it does not only require managerial skill and creative potential, but also the courage to take risks, in particular political risk of the position. This study also reveals that a Local Head has actually been a spokesperson since his candidacy in Local Head Election. This means that practically the role of a Local Head as spokesperson of development has started when he proposes his vision and mission at the Local Head Election. Thus, communication competency is one of the requirements for a local head to be successful in manifesting his vision and mission.

The manner and language used by Local Head in creating the characteristics of Banten people's socio-cultural life is by conducting participative leadership approach which motivates public involvement in the process of planning and implementing development. This manner is conducted by using the language and social communication style which is easy to understand by every group of people, present in Banten Province. In this context, the role of Local Head as spokesperson seems to show the appropriate language and manner for every group he faces. In this perspective, Nanus in $[9,10]$ states: "The leaderas a skilled speaker - is the chief advocate and negotiator for the organization and its vision with outside constituencies. Thus, the leader must actualize his role as supporter and simultaneously negotiator in socializing his leadership vision to the constituents."

To be an effective spokesperson, a leader must be the primary negotiator in speaking to other organization and building external relation network. This negotiation is needed in developing useful ideas, collecting resources support or conveying various information of the future of organization. In this context, development of effective communication function becomes vital in developing visionary leadership. This development of communication function is vital for the local head in building solid bureaucratic teamwork by empowering individuals in the team. In this dimension, functionally, the role of Local Head as spokesperson is actualized through Musrenbang forum proceeding from village to province or even national levels. Structurally, the role of Banten Provincial Local Head is actualized through consolidation, consultation, and coordination in the internal circle of Province Government and through consolidation, consultation, and coordination between governments. In this perspective of Musrenbang activity implementation and consolidation, consultation and coordination the Local Head actualize his role as negotiator as is meant by Nanus in $[9,10]$. However, the role of local head of Banten Province still seems unsuccessful in actualizing the role of negotiator. This can be identified from the lack of external relation network between the Governor and Regency/Municipal Head and public. This fact is revealed in the article of Yossihara and Saptowalyono [23] as follows: 
"The disharmonious relation with regencies/municipal governments can be perceived from the frequency of absence of regents/mayors in the events conducted by Banten Provincial Government. It is rarely that all regents/mayors gather with the Governor in an event, even in coordinative meeting, for example, Special Grand Assembly for the $9^{\text {th }}$ Anniversary of Banten Province on 4 October 2009. Not all regents/mayors attended the event in Banten House of Representative Building in Curug Regency, Serang. It was only Serang Regent Taufik Nuriman, Acting Mayor of South Tangerang M. Shaleh, and Deputy Regent of Lebak Amir Hamzah attended the event. Meanwhile the Mayor of Serang Bunyamin, Acting Regent of Pandeglang Erwan Kurtubi, Mayor of Cilegon Tubagus Aat Syafaat, Regent of Tangerang Ismet Iskandar, and Mayor of Tangerang Wahidin Halim did not appear. This absence is uncommon if the relations between the Governor and regents/mayors are really harmonious. However, it is often that regents/mayors do not attend the event conducted by Provincial Government for they have polemics."

In the context of coordinative relation with subordinate local leaders with their own authorities, Banten Governor Atut Chosiyah seems to be not really successful in playing the part of spokesperson for subordinating Regencies/Municipal heads particularly in developing various coordinative approaches in conveying information on the development direction, consolidating development resource supports, and integrating and harmonizing inter regional development performance of regencies/cities in the same provincial area, other provincial areas, and with central government. This is also mentioned by one informant of Banten Working Unit Head in Governor Atut Chosiyah era, stating:

"The problem faced is the lack of similar perception among governmental working units in determining development program and the weak coordination, both among Banten Provincial government and Regencies/Cities. The efforts that must be taken are improvement of interactive process through communities and dialogue between governmental working units, both provincial and regencies/municipal governments and development actors with the intention of improving harmony and synergy in the effort of accomplishing development goals."

Improvement of coordination effectiveness among working units of Provincial and Regencies/Municipal Governments must be the concern of a Governor in developing effective communication strategy with subordinating Regents and Mayors. This is due to the fact that both of them possess important authority in autonomy era; therefore a good relation is vital, particularly to harmonize development vision of the Governor and Mayors and Regents so that the role of Governor as spokesperson is really actualized. It shows that development of effective communication function is essential in developing visionary leadership.

\subsection{Local Head Role as a Direction Setter}

As the top executive of the implementation of government administrative system in Provincial level, and as the top manager responsible for the implementation of development management system, the role of Local Head of Banten Province appears to be vital and strategic for the success of the implementation of decentralization and local autonomy policy. There are many duties related to the implementation of this responsibility. One of the duties of Local Head leadership is giving administrative directions and managerial directions to all work units of the government. Field observation reveals that Local Head leadership duty is giving administrative directions, 
among others, local administrative procedures such as contained in the Decree of the Minister of Internal Affairs Number 54 Year 2010 on Implementation of Government Decree Number 8 Year 2008 on Stages, Composing Procedures, Control, and Evaluation of Further Local Development Plan Implementation, stipulating that each year during planning process, this LMTDP will be elaborated into Local Government Work Plan (RKPD) of Banten Provincial Government, which will be the reference for OPD in composing Work Plan (Renja) of OPD (Head of Provincial Parliament of Banten Province: 12 July 2011) [21].

In this dimension, the role of Local Head as direction setter seems conspicuous as development manager. As manager of LMTDP implementation, every budget year end or at the end of his office time, Local Head conveys performance accountability report over implementation of LMTDP. From this accountability report, the success rate of Local Head in commanding the implementation of governmental matters will be discovered. Also from this report, it will be known how development vision is realized into implementation of various development policies, programs, and activities. Thus, the capacity and integrity of Local Head leadership is closely attached to his success in achieving development vision. Apart from giving direction straight to heads of local apparatus organizations, Local Head also publishes several rules set together in line with the local long term development goals (Asda I Setda Banten Province: 23 July 2011) [22]. These joint directions with head of Provincial Parliament are contained in Local Stipulation on LLTDP.

Thus, in administrative dimension, Local Head directions as top executive become the implementation manual of various government administrative policies and development administrative; meanwhile, in technical dimension, Local Head directions become implementation manual for various administrative activities, including development activities. In this context, the role of Local Head as direction setter becomes vital for the implementation of effective, efficient and accountable government administrative activities. Considering the position of Local Head as political officer and simultaneously as top executive, automatically the role of Local Head as direction setter seems more conspicuous from other roles. This role among others is actualized from the authority of Local Head in setting policies and/or taking strategic decisions for implementation of government administrative system and development management system. Although in several matters Local Head needs to consult the head of legislative body and in certain matters determining local policies together, the role of Local Head as direction setter is still dominant. This domination of executive role places Local Head in a position as the first person responsible for the success or failure of government functions implementation. Government functions referred to are among others development function, public empowerment function, and public service function. Therefore, capacity and integrity of Local Head leadership become vital for actualization of the government functions implementation effectiveness. In this context, the role of Local Head as direction setter which in legal formal is actualized in form of publication of regulations such as Governor Stipulation, Governor Decree and other policies become vital for actualization of transparent, effective, efficient and accountable government functions implementation performance. These regulations become legal formal manual, guidance, and reference for implementation of various government policies and activities. Meanwhile, the role of Local Head as development manager is actualized in various activities of consolidation, consultation and coordination in order to actualize order, directedness and integration of implementation of various development policies and activities. In this dimension, the role of Local Head as direction setter appears from various directions and rules conveyed by Local Head as the leader of local apparatus organizations such as Local Secretary, Head of Agency, Head of Body and Head of Office. If the role of Local Head as direction setter can come in contact with all government internal administrative problems and also public administrative problems, the 
role of Local Head as development manager is more limited to government internal circle. However, the two roles become a unity of Local Head leadership channel. Thus, if the role of Local Head as direction setter is viewed as political officer and also top executive, the role of Banten Provincial Local Head as direction setter seems to be the most vital compared to the other roles. With this role, Local Head becomes an effective leader based on his capacity in implementing effective and efficient programs for the achievement of organization goals as is mentioned by Nanus in $[9,10]$. For that to happen, a Local Head must understand and implement basic principles of what is need to be conveyed in giving directions for government work units. Moreover, this study reveals the importance of interaction process inside government work units that can be actualized through formal approach and informal approach. Formal approach can be executed through work meetings and coordination meeting, while informal approach can be conducted by holding informal meeting and communication. The weak coordination between the leaders of bureaucratic work units and the weak coordination between bureaucracy work units seem to be frequent obstacles for the Governor in implementing managerial approach. As is stated by some sources that the one thing needed in provincial government is stronger coordination between working units where sectorial ego factor still frequently occurs.

The weak coordination is also shown from the ineffectiveness of budget implementation as is discovered by Financial Audit Agency (BPK) in 2012. A member of Provincial Parliament of Banten in budget field states: "Effectiveness of budget implementation is still far from adequate. It is signified by program entity, weak planning, weak competency, and weak managerial ... We recommend Madam Governor to take firm action against the Working Unit indiscipline in using Local Budget hence resulting in the discovery of LHP BPK." The irresoluteness of the Governor towards working unit rank is regarded as the cause of the many problematic programs discovered by BPK. The informant considers the Governor irresolute and permissive concerning in disciplinary of Working Unit officials in using Local Budget fund so that it is reported in Scrutiny Result Report of BPK in 2012. On this discovery, BPK issued Fair with Exception. Therefore, the Budget Body of the Provincial Parliament of Banten at that time asked Governor Atut to be more resolute towards mischievous Working Unit officials ${ }^{1}$.

Against this weakness, monitoring and evaluation need to be conducted by the Governor or a team specifically conducting the monitoring and evaluation, so that Governor's directions implemented by leaders of bureaucracy work units can be clearly observed. It means that a Local Head cannot just give directions and no longer concern on how the directions are implemented. Local Head must know exactly how the directions are executed by every bureaucratic work unit leaders. Thus, the directional function in Local Head leadership process can be appraised clearly. It will be clearer if the directions given by Local Head to leaders of bureaucratic work unit are accompanied by indicators measuring their success. Besides, this is related to bureaucratic organization culture transpired for long time, as is mentioned by some sources from Local Parliament of Banten Province. Concerning this, one declaration of the leaders of Provincial Local Parliament should be noted as follows:

"There are many obstructions I face during directive giving or assessment of the follow-up to that directive. In a careful observation, this obstruction derives more from organizational culture and the weakness in bureaucratic leadership in almost every bureaucratic working unit. For instance, when I give directive on the importance of transparency in planning and usage of budget, it seems that the directive is not entirely

${ }^{1}$ Retrieved from: http://www.beritasatu.com/nasional/139383-gubernur-atut-dinilai-tidak-tegasbiarkan-skpd-tak-disiplin-gunakan-apbd.html 
implemented, why, well it is due to the organizational culture itself. It could also be said that it is due to bureaucratic culture mentality. ${ }^{2,}$

The weakness in organizational culture and in bureaucratic leadership seems to be common problem in the bureaucratic circle of Banten Provincial government. It is shown among others in less productive and less efficient working culture of the apparatus in utilizing resources and the presence of organizational behavior that harms State interest. Weakness in bureaucratic leadership is shown among others in leadership behavior conducted more on the authority-holding approaches. Informal approach that is not based on office authority also needs to be conducted. Many government leaders are successful in making their leadership effective by conducting informal approach that is not entirely based on their authority. This informal approach seems to be actualized in the leadership process of Banten Provincial Governor. Instinctively, this approach may be attached to the personality of the Local Head. It means, motherly charisma actualized in leadership process of Banten Provincial Governor should have been more developed into one of the government leadership styles effective in overcoming several pathological bureaucratic obstacles. The resoluteness of a motherly approach must be pushed as the direction setter of the government and becomes the key to solve mischievous behavior or habitual culture of the subordinates.

\subsection{Local Head Role as a Coach}

Local Head role as a coach can be perceived as a leader who in the context of leadership is able to construct a solid and dependable work team for the implementation of various development policies and activities. It means that the role of Local Head as coach or guide is meant as a leadership concept directed at constructing a special team which is solid and dependable in implementing various policies, in particular policies that become basis for manifestation of development vision, namely actualizing public welfare. To and/or through this special team, Local Head gives policy and strategic directions to optimize economic development. In this context, to make effective the implementation of decentralization and local autonomy policies stipulated in Law Number 32 Year 2004 on Local Government, achievement of economic development goals is one of the requirements for actualization of public welfare [24]. In this dimension, economic sectors need to be directed by Banten Provincial Local Head for optimizing the manifestation of development vision in economic field for economic development, expansion of job opportunity, improvement of income per capita, and expansion of development-product distribution. Those economic sectors and the integration of their development among concerned local apparatus organizations are a set of interesting questions to answer. In this perspective, development vision becomes very functional in the process of Banten Provincial Local Head leadership manifestation.

Indeed, the phenomenon of local government implementation at the moment still shows misperception in viewing decentralization and local autonomy policies. This misperception causes some Local Heads to ignore the importance of inter local government relation in implementation of government administrative system and development management system. There is even an inclination of each local to operate on their own, although they are still in a united area. This inclination can create underdeveloped and developed regions. Therefore, the role of Local Head as coach is not limited to the matters of building a team in bureaucratic internal circle he leads namely provincial government bureaucratic circle. The matters of building a solid and dependable team between Provincial Local Head and City/Municipal Local Head are also vital. In fact, it is vital for Banten Provincial Governor who is still faced with the matters of inter-

${ }^{2}$ Interview with the head of Banten Provincial Parliament on 12 July 2011 
regional gap. If the team mentioned is built and become solid for handling the matters of inter-regional gap, then the role of Banten Provincial Local Head as coach can be a portrait of success of the Governor leadership that can be an example for other Governors. It is not easy to make several Local Head a solid team for handling the matters of interregional relation, since there are so many interests that are hard to unite, in particular political interest related to political office function. Thus, there are still some problems and obstacles faced by Banten Provincial Local Head in coordinating and integrating various government policies.

In the context of implementation of development planning system as stipulated in Law Number 25 Year 2004 on National Development Planning System, coordination and integration of various policies and programs among Province local apparatus organizations become vital. Therefore, various problems and obstacles need to be handled so that the development planning system becomes integrated. However, sectorial ego between present offices and between Regencies/Cities still occurs clearly and becomes a problem of its own. This is admitted by Governor Atut Chosiyah herself in an interview:

"I believe the problem or obstruction you mention derives more from internal circle of the government itself. Apart from the matter of human resources, other obstructive problem is sectoral ego emerging from differences of interest ${ }^{3 "}$.

One of the problems is the difference of interest between working units of Banten Provincial government which has the potential of inciting conflict ${ }^{4}$. Efforts must be taken by building conducive communication and conducting dialogues with the working units of the government so that the program planned can be implemented concurrent to the direction of policy set and development vision of Banten Province ${ }^{5}$. Difference of interest can occur due to difference in local condition and situation; but also due to the differences in direction of policies of Local Head of every region. Meanwhile, differences between bureaucratic working units in one region can occur due to prominence of sectorial ego by bureaucratic working units. On one hand, this prominence of sectorial ego is related to institutional function, but it can also relate to prestige of certain position or interest in correlation with budget usage interest of each bureaucratic working units. The problem of sectorial ego transpires since bureaucratic apparatus individual, by the authority possessed, accustomed himself to prioritize his own or his group's interest. This sectorial ego is the challenge of Governor Atut Chosiyah during her office term.

Solving this problem, the Governor creates a Special Team as supporting expert for Local Head. In this context, the role of Governor as coach is actualized in the creation of these special teams. Here in these teams the Governor enforces fulfillment of her vision and becomes successful in building the trust and communication between Heads of Offices.

This complies with the opinion of Nanus on how to become a good coach. Nanus in $[9,10]$ states that "you must let people know what you stand, what the vision means to you, and what you will do to make it happen. You must also be committed to the success of everyone in your organization, respecting them, building trust, helping them learn and grow, and teaching them how to constantly improve their ability to achieve the vision."

Formally, this team can consist of some bureaucratic officials possessing certain competency attached to certain structural position. Informally, this team can consist of some certain expert or person possessing relevant influence or expertise. Transparent communication strategy through this special team with consideration of the importance of

\footnotetext{
${ }^{3}$ Interview with Banten Provincial Governor on 12 Agustus 2011

${ }^{4}$ Interview with Asda I Setda of Banten Province on 23 July 2011

${ }^{5}$ Interview with the Banten Province Head of Social Department on 2 August 2011
} 
position, authority, and responsibility competencies of each side involved in the team is the key for Governor Atut in actualizing her role as a Local Head who can act as a coach.

\subsection{Local Head Role as an Agent of Change}

Life pattern is always changing following the development of circumstances or the change of time. Similarly, in the process of local government system implementation, there are some changes showing that some matters are more important than others. These changes are indeed intentional or expected, but there are also unintentional and unexpected changes. Thus, every Local Head cannot avoid the processes of changes in government strategic circle. The changes needed by Banten Province to realize development vision is constructing based on: (1) Development of local potency through social, economic and local culture engineering; (2) Utilizing Science and Technology and globalization opportunity for local development; (3) Construction of great scale physical projects; (4) Construction of synergetic partnership pattern with city/municipal and other locals; (5) Strengthening of Banten HR with Science and Technology insight; (6) Strengthening of regional endurance and security; (7) Development of City/Municipal area; and (8) Arrangement of Banten Provincial borders. The role that must be actualized by Local Head is by guiding all local apparatus organizations (LAO) in implementing activity programs in line with vision and mission of Banten Province and policy support in implementing vision and mission of Banten Province (Local Secretary of Banten Province: 12 July 2011).

The area development which includes these changes can proceed since Banten Province is positioned next to DKI Jakarta Province and becomes Java-Sumatera connecting area. In this position, Banten Province has strategic position and high economic value. With such position and local potency, Banten Province becomes industrial investment choice and simultaneously distribution choice for fulfilment of public needs in Sumatera. Therefore, contribution of Banten PDRB formation is stimulated more by the activities of management industry, trade, hotel and restaurant, and transportation and communication sectors. The matter of poverty in Banten Province is still a conspicuous public matter in particular in Lebak and Pandeglang districts. Therefore, the handling of poverty matters needs to be the focus of Local Head leadership in giving managerial directions to actualize changes into better condition. This demand for changes surely encounters some problems and obstructions. Various sources state that cultural problem is one of the most prominent. This is stated by Governor Atut herself who elaborates:

"In every matter there would be problems or obstructions. However, I find that cultural obstruction maybe the heaviest challenge for Governor of Banten in making changes. This cultural obstruction in my opinion derives from mental attitude and values of some parts of the public which, due to their restriction, are hesitant to accept changes. If it is forced on them, it will only create detrimental situation. Therefore, it is not easy being the figure that can trigger changes in the environment. There are many matters to handle in making changes in environment ${ }^{6}$."

The difficulties in changing culture do not occur only in public, but also in bureaucratic or business circles in Banten Province. For that, changes become an obligation to do both from the aspects of government management, cultural value and business ethic, and economic structure to be more productive and efficient. This challenge for changes requires control and direction during Governor Atut Chosiyah office term. However, the rise of Governor Atut into position itself has brought changes in culture. This is signified by the appearance of female figure as the first Female Governor in Indonesia. Although as affirmed by Rahman in [6] the presence of women in political space in developing

${ }^{6}$ Interview with Banten Provincial Governor on 12 Agustus 2011 
countries cannot be separated from the role of kinship such as family network. It means that public trust derives more from the factor of strong family. This is reinforced by the issue of familial interest which always surrounds the figure of Governor Atut Chosiyah. Moreover another change, difficult to conduct in Banten Province, is the change in government bureaucratic culture, which the Governor has been attempted by conducting bureaucratic management and supervision. However, apparent sectorial ego factor becomes prominent obstruction. Change of bureaucratic culture is difficult to conduct since it does not include only organizational culture, but also includes bureaucratic apparatus cultural mentality. If bureaucratic culture changes, government performance will also change. It means that if bureaucratic culture develop well, government performance will automatically become better. Referring to the discussion above, at least there are two conditional requirements needed in conducting changes harmonious to the characteristic of problems of Banten public. First, support of apparatus resource capability; second, support of public participation. Support of apparatus resource capability is required to actualize effective and efficient bureaucratic performance. Support of public participation is required to add value to implementation of various policies and activities of development. This is the challenge for Governor Atut Chosiyah in achieving her role as an agent of change.

\section{Conclusion}

To answer the goal of this article, namely analyzing how far Banten local head applies visionary leadership in the management of local government, particularly in localities newly applying local democracy. The opinion of Nanus in $[9,10]$ on the four vital roles of visionary leader becomes the reference. Developing the role of leader as spokesperson, as direction setter, as coach, and as agent of change seems to be a particular challenge in localities only recently applying local democracy such as Banten province. From the role of leader as spokesperson perspective, it seems that Governor of Banten has not been entirely successful in actualizing the role of negotiator. In context of coordinative relation with subordinating local head with their own authority, namely Mayors and Regents, Governor Atut Chosiyah has not been effective in developing various coordinating approaches in gathering supports from regencies/cities. This challenge must be essentially solved by a Governor in the era of local autonomy, considering that Mayors and Regents have wide authority that cannot be entirely intervened by Governor. Therefore, good relation becomes essential, particularly in harmonizing development vision of Governor with the Mayors and Regents so that the role of Governor as spokesperson can really be actualized. From the perspective of leader as direction setter, the weakness in coordination among leaders of bureaucratic working units (local apparatus) under the Governor often becomes obstruction for the Governor for conducting managerial approach. This is stated by some sources that sectoral ego is still often found. The irresoluteness of the Governor towards her subordinates is considered as the cause for many problematic programs. The weakness in organizational culture and in bureaucratic leadership seems to be common problem in Banten Provincial government's bureaucratic circle. This is shown in less productive and less efficient working culture of apparatus in using resources and the presence of organizational behavior detrimental to the state. The weakness in bureaucratic leadership among others is shown in leadership behavior conducted more with authority-holding approach.

From the perspective of leader as coach, Governor Atut has made a breakthrough in reducing problems in her governance. The prominent government problem in Banten Province is the matter of sectoral ego between offices. One of the causes of this problem is the difference in interest between working units of Banten Provincial government which has the potential of inciting conflict. To solve this problem, the Governor creates Special Team as supporting expert for Local Head. In this context, the role of Governor as 
coach is actualized in the creation of these special teams. Here in these teams the Governor forces fulfillment of her vision and becomes successful in building the trust and communication between Heads of Offices. Transparent communication strategy through this special team with consideration of the importance of position, authority, and responsibility competencies of each side involved in the team is the key for Governor Atut in actualizing her role as a Local Head who can act as a coach. From the perspective of leader as agent of change, one of the obstructions causing difficulties in conducting changes in Banten Province is the matter of culture, both in government and in public. The challenge for cultural changes in government organization circle is admitted as a big challenge requiring direction and control during the leadership of Governor Atut Chosiyah. Changes in bureaucratic culture are difficult to conduct since it does not only include organizational culture but also bureaucratic apparatus cultural mentality. If bureaucratic culture changes, government performance will change as well. It means that if bureaucratic culture develop well, government performance will automatically become better.

From the discussion above, it can be concluded that during the governance of Atut Chosiyah, the visionary leadership is still a challenge to be applied. However, in this era there are innovative efforts attempting to solve bureaucratic problems where the Governor is successful in playing the role of a good coach for her team. However, there are still many bureaucratic challenges requiring hard efforts of a Governor both as spokesperson, direction setter, and agent of change. This conclusion provides the picture that for a local head who manages recently established local government as the result of decentralization, the challenge of handling bureaucratic culture is the main problem. A local head is demanded to be more visionary so as to be able to materialize changes in the paradigm of government bureaucracy into better and more professional one.

\section{Acknowledgement}

This research is supported by University of Prof. Dr. Moestopo (Beragama), Jakarta, Indonesia.

\section{References}

[1] Greer, S.L., 2010. "How does decentralisation affect the welfare state? Territorial politics and the welfare state in the UK and US" in Journal of Social Politics (2010), 39, 2, 181-201 Cambridge University Press.

[2] Pratchett, L. 2004. "Local autonomy, local democracy and 'the new localism'." Journal of Political Studies, Volume 52, Issue 2 June 2004 pp 358-375.

[3] Panday, P.K. 2011. "Local government system in Bangladesh: how far is it decentralized". Lex Localis - Journal of Local Self Government, Vol 8, No 3, pp. 205-230, July 2011.

[4] Nankyung, C. 2007. "Local elections and democracy in Indonesia: the Riau Archipelago" in Journal of Contemporary Asia 37-3 Aug 2007: 326-345.

[5] Haugaard, M. 2010. "Democracy, political power and authority" in Social Research 77-4 (winter 2010).

[6] Rahman, M.M. (2015). International Migration and Development in South Asia (Vol. 96). Routledge.

[7] Hesselbein, F. (1997). The Organization of the Future. The Drucker Foundation Future Series. JosseyBass Inc., Publishers, 350 Sansome Street, San Francisco, CA 94104.

[8] Kouzes, J.M. \& B.Z. Posner. 2002. Winning the Productivity Race. Toronto: Lexington Books.

[9] Nanus, B. 1999. "A theory of rule governed behavior and organizational behavior management". Journal of Organizational Behavior Management, 12 (2).

[10] Nanus, B. 2002. Visionary Leadership. San Francisco; Jossey-Bass Publishers.

[11] Miller, B. W., Hotes, R. W., \& Terry, J. D. (Eds.). (1983). Leadership in higher education: A handbook for practicing administrators. Greenwood Publishing Group.

[12] Rasyid, M. R. (2004). The policy of decentralization in Indonesia. Reforming intergovernmental fiscal relations and the rebuilding of Indonesia, 65.

[13] Jackson, T. A., Meyer, J. P., \& Wang, X. H. (2013). Leadership, commitment, and culture: A metaanalysis. Journal of Leadership \& Organizational Studies, 20(1), 84-106.

[14] Yukl, G. 2007. Kepemimpinan dalam Organisasi. (edisi ke 5). Jakarta: Indeks.

[15] Koentjaraningrat. 1971. Manusia dan Kebudayaan di Indonesia. Jakarta: Djambatan 
[16] Boeke, J. H. (1953). Economics and economic policy of dual societies as exemplified by Indonesia. AMS Press.

[17] Toffler, A. 1971. Future Shock. New York: Bantam Books.

[18] Sugiarto, B.A. (2009), Menuju Kepemimpinan Transformasional, Lead Institute.

[19] Sanapiah, A., Dimensi Kepemimpinan Aparatur dalam Perspektif Pelayanan Publik: Building the Trust, Jakarta: STIA-LAN RI.

[20] Banten Provincial Government. 2007. LMTDP of Banten Province Year 2007-2012.

[21] Banten Provincial Government. 2010. Local Budget of Banten Province 2010.

[22] Banten Provincial Government. 2008. Collection of Local Decrees on Formation of Banten Area Apparatus Organization Year 2008.

[23] Yossihara, A. and Saptowalyono, C.A. 2010. "Disharmoni terjadi sepanjang masa". Kompas Daily. Wednesday, 27 January 2010 edition.

[24] The Republic of Indonesia. 2.4. Law Number 32 Year 2004 on Local Government. Jakarta. 